\title{
PENGUNGKAPAN LINGKUNGAN, PROFITABILITAS DAN NILAI PERUSAHAAN
}

\author{
Iwan Setiadi $^{1}$, Yumniati Agustina ${ }^{2}$ \\ Institut Tehnologi dan Bisnis Ahmad Dahlan Jakarta \\ setiadi_0700@yahoo.com
}

\begin{abstract}
This study aims to examine the effect of environmental disclosures on firm value by using profitability as a moderating variable. The research sample is all companies listed on the Indonesia Stock Exchange. The sampling technique used in this study was purposive sampling, which consisted of 143 companies. The analysis of this study uses moderated regression analysis. The results of this study indicate that environmental disclosure has a positive and significant effect on firm value. Proability strengthens the influence of environmental disclosures on firm value. The more environmental information disclosed by the company, the higher the trust of stakeholders in the company, so as to encourage stakeholders to help and cooperate with companies in earning profits, the increase in profits encourages an increase in the value of the company itself.
\end{abstract}

Keywords: environmental disclosure, profitability, firm value

\begin{abstract}
ABSTRAK
Penelitian ini bertujuan untuk menguji pengaruh pengungkapan lingkungan terhadap nilai perusahaan dengan menggunakan profitabilitas sebagai variabel pemoderasi. Sampel penelitian ini merupakan seтиa perusahaan yang terdaftar di Bursa Efek Indonesia. Teknik sampling yang digunakan dalam penelitian ini adalah purposive sampling, yang terdiri dari 143 perusahaan. Analisis penelitian ini menggunakan moderated regression analysis. Hasil penelitian ini menunjukkan bahwa pengungkapan lingkungan berpengaruh positif terhadap nilai perusahaan. Proitabilitas memperkuat pengaruh pengungkapan lingkungan terhadap nilai perusahaan. Semakin banyak informasi lingkungan yang diungkapkan oleh perusahaan, maka semakin tinggi kepercayaan stakeholders terhadap perusahaan, sehingga mendorong stakeholders untuk membantu dan bekerjasama dengan perusahaan dalam memperoleh laba, peningkatan laba tersebut mendorong peningkatan nilai perusahaan itu sendiri.
\end{abstract}

Kata Kunci: pengungkapan lingkungan, profitabilitas, nilai perusahaan

\section{PENDAHULUAN}

Penelitian ini bertujuan untuk menguji pengaruh pengungkapan lingkungan terhadap nilai perusahaan dengan menggunakan profitabilitas sebagai variabel pemoderasi. Pengungkapan lingkungan diukur dengan proksi indeks pengungkapan lingkungan perusahaan. Profitabilitas diukur dengan proksi Return On Assets (ROA). Nilai perusahaan dalam penelitian ini diukur dengan proksi Tobin's $Q$ (Chung dan Pruitt, 1994).

Fenomena yang menjadi dasar penelitian ini adalah banyaknya kejadian kerusakan lingkungan yang disebabkan oleh kegiatan operasional perusahaan sehingga berdampak pada penurunan nilai saham perusahaan. Kasus PT. Lapindo Brantas Inc yang melakukan kelalaian dalam pengeboran minyak dan gas bumi di Sidoarjo telah berdampak negatif terhadap masyarakat, lingkungan (Detiknews.com, 2006) dan mengakibatkan menurunnya harga saham PT. Energi 
Mega Persada, Tbk. sebagai pemegang saham mayoritas PT. Lapindo Brantas Inc. Fenomena ini memperkuat gagasan bahwa kegiatan perusahaan yang tidak dilandasi oleh etika dan moral dapat berdampak negatif terhadap nilai perusahaan itu sendiri (Parmar dkk, 2010). Fenomena tersebut memperlihatkan masalah penurunan nilai perusahaan dapat terjadi karena menurunnya kepercayaan stakeholders terhadap perusahaan.

Pernyataan tersebut dapat diartikan bahwa perusahaan dalam mewujudkan tujuannya harus dilandasi oleh etika dan moral, sehingga kegiatan perusahaan dapat dipertanggungjawabkan dan mampu memberikan manfaat bagi seluruh stakeholder-nya. Hal ini menjadi tantangan dan tugas manajemen untuk mempertahankan atau meningkatkan kinerja dan harga pasar saham melalui berbagai kebijakan, sehingga nilai perusahaan dapat meningkat (Suhardjanto dan Nugraheni, 2012). Di samping itu perusahaan dalam menjalankan kegiatannya harus dilandasi oleh etika dan moral (Freeman, 1984), memperhatikan kepentingan dan melindungi stakeholders-nya (Komite Nasional Kebijakan Governance/KNKG, 2006).

Pengungkapan lingkungan merupakan bentuk akuntabilitas perusahaan (Cormier, Magnan dan Velthoven, 2005). Perusahaan merupakan bagian dari konteks sosial dan kelompok stakeholders yang memiliki pengaruh langsung terhadap keberlangsungan usaha (Schadewitz dan Niskala, 2010; Lu dan Abeysekera, 2014). Pendapat serupa juga disampaikan oleh Richardson dan Welker (2001) yang menyatakan bahwa pengungkapan lingkungan mampu memainkan peran yang mirip dengan pengungkapan keuangan. Jika informasi tentang kegiatan lingkungan relevan dengan penilaian prospek perusahaan, maka peningkatan pengungkapan kegiatan lingkungan memiliki efek yang sama seperti pengungkapan keuangan (Richardson dan Welker, 2001).

Profitabilitas merupakan unsur penting bagi perusahaan untuk mempertahankan kelangsungan usahanya. Kasmir (2010) menyatakan bahwa profitabilitas merupakan faktor yang dapat mempengaruhi nilai perusahaan. Jika manajemen mampu mengelola perusahaan dengan baik, maka biaya yang dikeluarkan lebih kecil, sehingga laba yang dihasilkan menjadi lebih besar. Besar atau kecilnya laba ini yang akan mempengaruhi nilai perusahaan. Profitabilitas merupakan indikator yang sering digunakan investor untuk melihat nilai suatu perusahaan. Berdasarkan penjelasan tersebut peneliti menduga bahwa profitabilitas dapat memoderasi pengaruh pengungkapan lingkungan terhadap nilai perusahaan. Hal ini didasari oleh asumsi bahwa semakin tinggi tingkat profitabilitas yang dicapai perusahaan, maka semakin banyak item pengungkapan lingkungan yang diungkapkan oleh perusahaan yang pada akhirnya berdampak terhadap peningkatan nilai perusahaan.

Penelitian ini bermanfaat: (1) memberikan gambaran mengenai tingkat pengungkapan lingkungan perusahaan di Indonesia, (2) memberikan gambaran mengenai pengungkapan lingkungan sebagai mekanisme bagi perusahaan dalam menjaga hubungan baik dan kepercayaan stakeholders, (3) bagi regulator sebagai bahan pertimbangan untuk memperluas cakupan atas regulasi dan standar lingkungan yang telah disusun oleh pemerintah. Secara umum penelitian ini dilakukan pada konteks yang berbeda dengan berbagai penelitian sebelumnya, dengan objek penelitian pada salah satu negara berkembang. Keterbaruan penelitian ini terletak pada: (a) pengujian moderasi profitabilitas pada pengaruh pengungkapan lingkungan terhadap nilai perusahaan, (b) menggunakan indeks 
pengungkapan lingkungan yang disusun dan diformulasikan kembali berdasarkan kombinasi dari berbagai indeks pada penelitian terdahulu dan GRI 4.0 (2013), (c) menggunakan variabel profitabilitas sebagai pemoderasi pengaruh pengungkapan lingkungan terhadap nilai perusahaan, (d) peneliti sebelumnya fokus menjelaskan peran pengungkapan informasi pada perusahaan-perusahaan besar di negara maju, namun belum banyak penelitian yang mengungkapkan tentang peran pengungkapan informasi pada suatu perusahaan di negara berkembang khususnya di Indonesia.

\section{LITERATURE REVIEW \\ Stakeholder Theory}

Stakeholders merupakan kelompok atau individu yang dapat mempengaruhi atau dipengaruhi oleh perusahaan dalam usaha mewujudkan tujuannya (Freeman, 1984). Dengan perspektif yang lebih komprehensif, Clarkson (1995) mendefinisikan stakeholders sebagai individu atau kelompok yang memiliki klaim, kepemilikan, hak dan kepentingan dengan kegiatan perusahaan pada waktu lalu, sekarang dan yang akan datang. Stakeholder theory dapat didefinisikan sebagai hubungan dan kepercayaan antara manajemen perusahaan dengan stakeholders-nya secara berkelanjutan dalam mewujudkan tujuan perusahaan yaitu meningkatkan nilai perusahaan dan mensejahterakan stakeholders.

Stakeholder theory lahir dengan asumsi dasar bahwa etika merupakan bagian dari kegiatan bisnis (Freeman, Wicks dan Parmar, 2004). Manajemen dapat mengartikulasikan rasa kebersamaan dari kontrak yang telah dibuat dan kepercayaan yang diperoleh, sehingga mendorong stakeholders dapat bekerja sama dengan perusahaan (Freeman dkk, 2004). Pernyataan tersebut mengandung arti bahwa manajemen harus jelas dalam menjalankan bisnis, khususnya hubungan seperti apa yang manajemen inginkan dan butuhkan untuk membuat stakeholders membantu perusahaan dalam mewujudkan tujuannya (Freeman dkk, 2004). Menjalin dan mengembangkan hubungan baik, menginspirasi, dan menciptakan komunikasi dengan stakeholders secara berkelanjutan merupakan upaya perusahaan untuk memberikan hasil terbaik dalam mewujudkan tujuan dan meningkatkan nilai perusahaan (Freeman dkk, 2004).

\section{Nilai Perusahaan}

Fama (1978) menyatakan nilai perusahaan merupakan tingkat keberhasilan perusahaan dalam mengelola sumber dayanya yang tercermin pada harga saham. Modigliani dan Miller (1963) menyatakan bahwa nilai perusahaan merupakan penjumlahan nilai pasar utang dengan nilai pasar saham. Penman (2013) mendefinisikan nilai perusahaan sebagai nilai pengembalian suatu perusahaan yang diharapkan lebih tinggi dari tingkat kewajibannya.

Nilai perusahaan dapat diukur dengan melihat perkembangan harga saham di pasar modal (Keown, 2000). Nilai perusahaan dapat diproksikan dengan Tobin's $Q$ (modified Tobin's $Q$ ) dan diukur dengan menghitung rasio market value of all outstanding shares ditambah dengan total hutang dibagi total aset (Chung dan Pruitt, 1994). Nilai Tobin's $Q$ menggambarkan suatu kondisi peluang investasi yang dimiliki perusahaan, potensi pertumbuhan perusahaan dan ukuran kinerja perusahaan dari sisi potensi nilai pasar suatu perusahaan.

\section{Pengungkapan Lingkungan}

Menurut Scott (2012) pada dasarnya jenis informasi yang diungkapkan perusahaan terbagai 2 (dua) dua yaitu mandatory disclosure dan voluntary 
disclosure. Financial Accounting Standards Board/FASB (2001) mendefinisikan voluntary disclosure sebagai informasi yang dipublikasikan secara sukarela oleh perusahaan, namun tidak termasuk informasi dasar yang diwajibkan untuk dipublikasikan, baik oleh prinsip akuntansi yang berlaku umum maupun lembaga regulasi.

Salah satu bentuk pengungkapan sukarela adalah pengungkapan informasi lingkungan. Pengungkapan lingkungan merupakan informasi yang berhubungan dengan dampak kegiatan masa lalu, saat ini dan masa depan pengelolaan lingkungan sebagai akibat kegiatan perusahaan (Campbell, 2004). Pengungkapan lingkungan merupakan bentuk akuntabilitas perusahaan (Cormier, Magnan dan Velthoven, 2005), wujud etika dan moral perusahaan (Freeman, 1984) dan upaya perusahaan untuk melindungi stakeholders-nya (KNKG, 2006). Hal ini disebabkan karena perusahaan merupakan bagian dari konteks sosial dan kelompok stakeholders yang memiliki pengaruh langsung terhadap keberlangsungan usaha (Schadewitz dan Niskala, 2010; Lu dan Abeysekera, 2014). Dengan demikian perusahaan dalam mewujudkan tujuannya harus dilandasi oleh etika dan moral, sehingga kegiatan perusahaan dapat dipertanggungjawabkan dan mampu memberikan manfaat bagi seluruh stakeholder-nya (Parmar dkk, 2010).

Hasil penelitian sebelumnya menunjukkan hasil yang inkonsisten. Penelitian yang dilakukan oleh Schadewitz dan Niskala (2010), Clarkson dkk (2013), Serveas dan Tamayo (2013), Plumlee dkk (2015), Cordiero dan Tewari (2015), Suhardjanto dan Nugraheni (2012) membuktikan bahwa pengungkapan lingkungan berpengaruh positif terhadap nilai perusahaan. Peneliti berasumsi bahwa semakin banyak informasi yang diungkap oleh perusahaan terkait dengan kegiatan operasionalnya, maka mampu menumbuhkan kepercayaan stakeholders dalam membantu perusahaan untuk mewujudkan tujuannya. Atas dasar penelitian terdahulu tersebut dan argumentasi di atas, maka hipotesis peneltian ini dirumuskan sebagai berikut.

\section{$\mathrm{H}_{1}$ : Pengungkapan Lingkungan berpengaruh positif terhadap nilai perusahaan \\ Profitabilitas}

Menurut Wahidahwati (2002) menyatakan bahwa profitabilitas merupakan gambaran dari kinerja manajemen dalam mengelola perusahaan. Profitabilitas adalah faktor yang memberikan kebebasan dan fleksibilitas kepada manajemen untuk mengungkapkan informasi mengenai program perlindungan lingkungan kepada para stakeholders secara lebih luas (Florence dkk, 2004). Hubungan antara profitabilitas dengan pengungkapan lingkungan perusahaan telah menjadi postulat (anggapan dasar) yang mencerminkan pandangan bahwa semakin tinggi tingkat profitabilitas perusahaan, maka semakin besar pengungkapan informasi lingkungan (Anggraini, 2006).

Hasil penelitian terdahulu yang dilakukan oleh Nurhayati (2013), Mardiyati, Ahmad, dan Putri (2012), Prasetyorini (2013), Dj, Artini, dan Suarjaya (2012), Wulandari (2013), Dewi dan Wirajaya (2013), Wijaya dan Sedana (2015) membuktikan bahwa profitabilitas berpengaruh positif terhadap nilai perusahaan. Berdasarkan hasil penelitian terdahulu tersebut peneliti menduga bahwa profitabilitas dapat memoderasi pengaruh pengungkapan lingkungan terhadap nilai perusahaan. Hal ini didasari oleh asumsi bahwa semakin tinggi tingkat profitabilitas yang dicapai perusahaan, maka semakin banyak item pengungkapan 
lingkungan yang diungkapkan oleh perusahaan yang pada akhirnya berdampak terhadap peningkatan nilai perusahaan. Adapun hipotesis penelitiannya adalah:

$\mathrm{H}_{2}$ : Profitabilitas memperkuat pengaruh pengungkapan lingkungan terhadap nilai perusahaan

\section{METODE PENELITIAN}

Sampel dalam penelitian ini adalah perusahaan manufaktur yang terdaftar di Bursa Efek Indonesia (BEI) pada periode tahun 2010 - 2017. Teknik pengumpulan data pada penelitian ini menggunakan data sekunder, berupa laporan tahunan perusahaan manufaktur yang listing di BEI. Data sekunder diperoleh dari situs www.idx.co.id dan dari website masing-masing perusahaan sampel.

Variabel dependen yang ada pada penelitian ini adalah nilai perusahaan yang diproksikan dengan Tobin's $Q$.

$$
\operatorname{Tobin}^{\prime} Q=\frac{(\mathrm{MVS}+\mathrm{D})}{\text { Total Aset }}
$$

Q $\quad=$ Nilai perusahaan.

MVS = Market Value of all outstanding shares.

$\mathrm{D} \quad=$ Hutang.

TA $\quad=$ Total aset.

Variabel independen dalam penelitian ini adalah luas pengungkapan lingkungan perusahaan yang diukur dengan menggunakan angka indeks (ED index).

$$
\text { ED indeks }=\frac{\sum \text { item pengungkapan lingkungan yang diungkapkan perusahaan }}{\sum \text { Total seluruh item }}
$$

Penelitian ini menggunakan indeks pengungkapan yang dikembangkan oleh Setiadi (2016) yang berjumlah 44 item pengungkapan lingkungan perusahaan.

Variabel moderasi pada penelitian ini adalah profitabilitas yang diukur dengan menggunakan proksi Return on Assets (ROA).

$$
\text { ROA }=\frac{\text { Laba Setelah Pajak }}{\text { Total Aset }}
$$

Penelitian ini juga menggunakan variabel kontrol antara lain tipe industri menggunakan variabel dummy, yaitu 2 untuk industri dasar dan kimia, 1 untuk aneka industri dan 0 untuk industri barang konsumsi. Ukuran perusahaan diukur dengan total aktiva yang dimiliki perusahaan dalam kurun waktu satu tahun (LnAsset). Umur perusahaan diukur dengan jumlah umur perusahaan sejak listing di Bursa Efek Indonesia hingga tahun 2017.

\section{HASIL PENGUJIAN HIPOTESIS DAN PEMBAHASAN}

Tabel 1 memberikan gambaran statistik deskriptif dari setiap variabel khususnya minimum, maksimum, rata-rata, standar deviasi, dan jumlah pengamatan.

\begin{tabular}{lcccc}
\multicolumn{5}{c}{ Tabel 1. Statistik Deskriptif } \\
\multicolumn{1}{c}{ Variabel } & Min & Max & Mean & Std Deviation \\
\hline Pengungkapan lingkungan & 0,020 & 0,410 & 0,14374 & 0,078403 \\
ROA & 0,000 & 3,190 & 0,09017 & 0,155959 \\
Tobins Q & 0,290 & 27,720 & 1,94607 & 2,634813
\end{tabular}




$\begin{array}{lcccr}\text { Ukuran perusahaan } & 11,270 & 19,500 & 14,55078 & 1,673276 \\ \text { Umur perusahaan } & 1,000 & 36,000 & 19,31785 & 7,041756\end{array}$

\section{Uji Asumsi Klasik}

Penelitian ini memenuhi seluruh pengujian asumsi klasik. Untuk uji normalitas penelitian ini menggunakan central limit theorem, karena data $\mathrm{n}>$ 30 (Gujarati dan Porter, 2009), tidak terjadi multokolinieritas antar variabel independen, tidak terdapat adanya heteroskedastisitas dan tidak terdapat gejala autokorelasi.

\section{Uji Hipotesis}

Hasil uji koefisien determinasi $\left(\mathrm{R}^{2}\right)$ yang terlihat pada Tabel 2 menunjukkan koefisien determinasi (Adjusted $\mathrm{R}^{2}$ ) adalah 0,173 atau 17,3\% ini berarti bahwa variabel independen memiliki pengaruh terhadap variabel dependen sebesar 17,3\%. Hasil uji $\mathrm{F}$ pada Tabel 2 menunjukkan semua variabel independen secara simultan mempengaruhi variabel dependen.

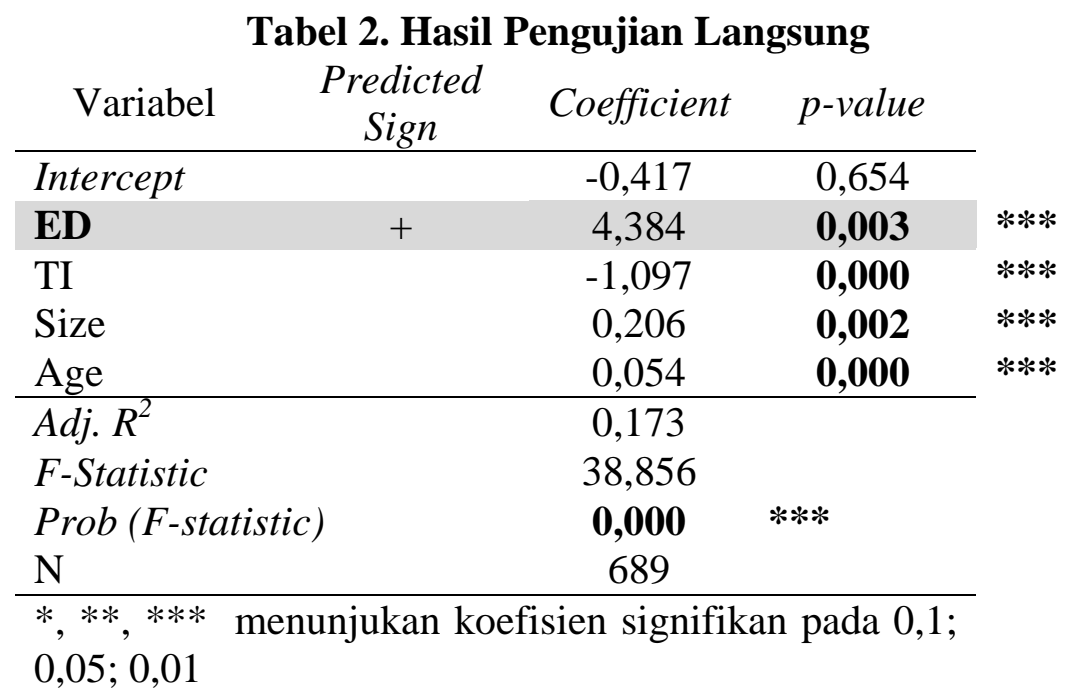

Keterangan Variabel:

ED : Pengungkapan Lingkungan

TI : Tipe industri

TA : Total aset

AGE : Umur Perusahaan

Berdasarkan Tabel 2, variabel pengungkapan lingkungan memiliki nilai koefisien regresi sebesar 4,384 dengan signifikansi sebesar 0,003 $<0,05$ sehingga hipotesis 1 diterima. Hasil ini sesuai dengan penelitian yang dilakukan oleh Schadewitz dan Niskala (2010), Suhardjanto dan Nugraheni (2012), Clarkson, Fang, Li dan Richardson (2013), Serveas dan Tamayo (2013), Plumlee, Brown, Hayes, dan Marshall (2015), dan Cordiero dan Tewari (2015). Hasil penelitian ini sesuai dengan pendapat Cormier dan Magnan (2007) yang menyatakan bahwa pengungkapan lingkungan digunakan oleh investor untuk lebih menilai prospek laba perusahaan dan mengurangi ketidakpastian usaha. Pengungkapan lingkungan menunjukkan potensi kewajiban dan komitmen lingkungan yang memungkinkan investor untuk merevisi penilaian terhadap risiko keuangan dan kegiatan 
perusahaan (Cormier dan Magnan, 2007). Dengan demikian semakin banyak informasi lingkungan yang diungkapkan, maka semakin tinggi kepercayaan dan dukungan stakeholders terhadap pencapaian tujuan perusahaan. Disamping itu semakin banyak informasi lingkungan yang diungkapkan dapat mengurangi biaya modal, mengurangi ketidakpastian usaha, meminimalisasi risiko, menilai prospek laba dan meningkatkan kredibilitas laporan keuangan perusahaan.

\begin{tabular}{|c|c|c|c|c|c|c|c|c|c|c|}
\hline \multirow{3}{*}{ Variabel } & \multicolumn{10}{|c|}{ Tabel 3. Hasil Pengujian Variabel Moderasi } \\
\hline & \multirow{2}{*}{$\begin{array}{l}\text { Predicted } \\
\text { Sign }\end{array}$} & \multicolumn{3}{|c|}{ Pengujian Langsung } & \multicolumn{6}{|c|}{ Pengujian Moderasi } \\
\hline & & \multirow{2}{*}{$\begin{array}{c}\text { Coef. } \\
-0,417\end{array}$} & \multicolumn{2}{|c|}{ p-value } & \multirow{2}{*}{$\begin{array}{c}\text { Coef. } \\
-0,575\end{array}$} & \multicolumn{2}{|c|}{ p-value } & \multirow{2}{*}{$\begin{array}{c}\text { Coef. } \\
-0,410\end{array}$} & \multicolumn{2}{|c|}{ p-value } \\
\hline Intercept & & & 0,654 & & & 0,488 & & & 0,597 & \\
\hline $\mathrm{ED}$ & + & 4,384 & $\mathbf{0 , 0 0 3}$ & $* * *$ & 4,117 & $\mathbf{0 , 0 0 2}$ & $* * *$ & $-3,827$ & $\mathbf{0 , 0 0 9}$ & $* * *$ \\
\hline ROA & + & & & & 7,082 & $\mathbf{0 , 0 0 0}$ & $* * *$ & $-0,359$ & 0,689 & \\
\hline $\mathrm{ED} * \mathrm{ROA}$ & + & & & & & & & 70,754 & $\mathbf{0 , 0 0 0}$ & $* * *$ \\
\hline TI & & $-1,097$ & $\mathbf{0 , 0 0 0}$ & $* * *$ & $-0,914$ & $\mathbf{0 , 0 0 0}$ & $* * *$ & $-0,778$ & $\mathbf{0 , 0 0 0}$ & $* * *$ \\
\hline $\mathrm{TA}$ & & 0,206 & 0,002 & $* * *$ & 0,175 & $\mathbf{0 , 0 0 3}$ & $* * *$ & 0,027 & $\mathbf{0 , 0 0 0}$ & $* * *$ \\
\hline AGE & & 0,054 & 0,000 & $* * *$ & 0,035 & $\mathbf{0 , 0 0 3}$ & $* * *$ & 0,027 & 0,016 & $* * *$ \\
\hline $\operatorname{Adj.} R^{2}$ & & 0,173 & & & 0,341 & & & 0,424 & & \\
\hline$F$-Statistic & & 36,856 & & & 72,312 & & & 85,549 & & \\
\hline Prob (F-stat & stic) & 0,000 & $* * *$ & & 0,000 & $* * *$ & & 0,000 & $* * *$ & \\
\hline $\mathrm{N}$ & & 689 & & & 689 & & & 689 & & \\
\hline
\end{tabular}

$*, * *, * * *$ menunjukan koefisien signifikan pada 0,$1 ; 0,05 ; 0,01$

Keterangan Variabel:

$\begin{array}{ll}\text { ED : Pengungkapan lingkungan } & \text { TI : Tipe industri } \\ \text { ROA : Profitabilitas } & \text { AGE : Umur Perusahaan }\end{array}$

Size : Ukuran perusahaan

Berdasarkan Tabel 3, variabel ED * ROA memiliki nilai koefisien regresi sebesar 70,754 dengan signifikansi sebesar 0,000 <0,05 sehingga hipotesis 2 diterima. Sepengetahuan peneliti belum ditemukan penelitian yang menggunakan variabel profitabilitas sebagai pemoderasi pengaruh pengungkapan lingkungan terhadap nilai perusahaan. Hasil ini menunjukkan bahwa stakeholders membutuhkan informasi tambahan dalam mengevaluasi peran perusahaan dalam berbagai hal, salah satunya adalah mengenai tanggung jawab lingkungan. Dampak negatif yang ditimbulkan akibat kegiatan usaha yang merusak lingkungan dapat merusak hak dan kepentingan stakeholders (Huang dan Kung, 2010). Disamping itu pengungkapan lingkungan menunjukkan potensi kewajiban lingkungan dan komitmen yang memungkinkan kreditur untuk merevisi penilaian terhadap risiko keuangan dan kegiatan perusahaan (Cormier dan Magnan, 2007), serta meningkatkan kredibilitas laporan keuangan (Clarkson dkk, 2013), sehingga mampu meningkatkan nilai perusahaan. Dengan demikian semakin banyak informasi lingkungan yang diungkapkan oleh perusahaan, maka semakin tinggi kepercayaan stakeholders terhadap perusahaan, sehingga mendorong stakeholders untuk membantu dan bekerjasama dengan perusahaan dalam memperoleh laba, peningkatan laba tersebut mendorong peningkatan nilai perusahaan itu sendiri. 


\section{KESIMPULAN, KETERBATASAN DAN SARAN}

Berdasarkan hasil analisis yang telah dilakukan, dapat ditarik kesimpulan bahwa pengungkapan lingkungan berpengaruh positi terhadap nilai perusahaan. Profitablitas mampu memperkuat pengaruh pengungkapan lingkungan terhadap nilai perusahaan. Keterbatasan dalam penelitian ini adalah peneliti tidak membahas tentang kualitas item pengungkapan lingkungan yang diungkapkan oleh perusahaan. Banyaknya item yang diungkapkan tidak menunjukkan kualitas pengungkapan informasi perusahaan. Untuk penelitian selanjutnya diharapkan penelitian dapat menggunakan pendekatan kualitatif, sehingga seluruh informasi mengenai lingkungan yang diungkapkan dapat diketahui dan dapat memberikan gambaran secara menyeluruh tentang penerapan pengungkapan lingkungan perusahaan di Indonesia.

\section{DAFTAR PUSTAKA}

Anggraini, Fr. R. R. 2006. Pengungkapan informasi sosial dan faktor-faktor yang mempengaruhi pengungkapan informasi sosial dalam laporan keuangan tahunan. Simposium Nasional Akuntansi IX. Padang. 23-26 Agustus.

Campbell, David. 2004. A longitudinal and cross-sectional analysis of environmental disclosure in UK companies - a research note. The British Accounting Review, 36(1): 107-117.

Chung, Kee H, dan Stephen.W. Pruitt. 1994. A simple approximation of tobin's q. Financial Management, 23(3): 70-74.

Clarkson, Max B.E. 1995. A stakeholder framework for analyzing and evaluating corporate social performance. Academy of Management Review, 20(1): 92117.

Clarkson, Peter M, Xiaohua Fang, Yue Li, dan Gordon Richardson. 2013. The relevance of environmental disclosures: Are such disclosures incrementally informative?. Journal of Accounting and Public Policy, 32(5): 410-431.

Cordeiro, James J., dan Manish Tewari. 2015. Firm characteristics, industry context, and investor reactions to environmental CSR: A stakeholder theory approach. Journal of Business Ethics, 130(4): 833-849.

Cormier, Denis, Michel Magnan, dan Barbara Van Velthoven. 2005. Environmental disclosure quality in large German companies: Economic incentives, public pressures or institutional conditions?. European Accounting Review, 14(1): 3-39

Cormier, Denis dan Michel Magnan. 2007. The revisited contribution of environmental reporting to investors' valuation of a firm's earnings: An international perspective. Ecological Economics, 62(3): 613-626.

Detiknews.com. 08 Juni 2006. Lumpur PT Lapindo Mulai Mengancam 3 Desa di Jati Rejo, Retrieved: 13 Juli 2013, from http://news.detik.com/berita/611999/ lumpur-pt-lapindo-mulai-mengancam3-desa-di-jati-rejo.

Dewi, Ayu Sri Mahatma dan Ary Wirajaya. 2013. Pengaruh struktur modal, profitabilitas dan ukuran perusahaan pada nilai perusahaan. E-Jurnal Akuntansi Universitas Udayana, 4(2): 358-372.

Dj, Alfredo Mahendra, Luh Gede Sri Artini dan A.A Gede Suarjaya. 2012. Pengaruh kinerja keuangan terhadap nilai perusahaan pada perusahaan manufaktur di Bursa Efek Indonesia. Jurnal Manajemen, Strategi Bisnis, dan Kewirausahaan, 6(2): 130-138. 
Fama, Eugene F. 1978. The effects of a firm's investment and financing decisions on the welfare of its security holders. The American Economic Review, 68(3): 272-284.

Florence, Devina, Suryanto dan Zulaikha. 2004. Pengaruh karakteristik perusahaan terhadap pengungkapan sosial dalam laporan tahunan perusahaan go public di Bursa Efek Jakarta (BEJ). Jurnal Maksi, 4(1): 161177.

Financial Accounting Standards Board (FASB), 2001. Improving business reporting: insights into enhancing voluntary disclosures. Working paper. FASB

Freeman, R. Edward. 1984, Strategic management: A stakeholder approach. Pitman Publishing Inc, USA.

Freeman, R. Edward, Andrew C. Wicks, dan Bidhan Parmar. 2004. Stakeholder theory and "the corporate objective revisited". Organization Science, 15(3): 364-369.

Gujarati, Damodar N. dan Dawn C. Porter. 2009. Basic Econometric 5thEdition. McGraw -Hill: New York.

Huang, Cheng-Li, dan Fan-Hua Kung. 2010. Drivers of environmental disclosure and stakeholder expectation: Evidence from Taiwan. Journal of Business Ethics, 96(3): 435-451

Kasmir. 2010. Analisis Laporan Keuangan. Jakarta: PT Raja Grafindo Persada.

Keown, Arthur J. 2000. Dasar-Dasar Manajemen Keuangan. Salemba Empat, Jakarta.

Komite Nasional Kebijakan Governance. 2006. Pedoman Umum Good Corporate Governance Indonesia. Retrieved: 2 Agustus 2013, from http://www.ecgi.org/codes/documents/indonesia_cg_2006_id.pdf diunduh tanggal 20 Agustus 2013

Lu, Yingjun, dan Indra Abeysekera. 2014. Stakeholders' power, corporate characteristics, and social and environmental disclosure: Evidence from China. Journal of Cleaner Production, 64(1): 426-436.

Mardiyati, Umi, Gatot Nazir Ahmad dan Ria Putri. 2012. Pengaruh kebijakan dividen, kebijakan hutang dan profitabilitas terhadap nilai perusahaan manufaktur yang terdaftar di BEI periode 2005-2010. Jurnal Riset Manajemen Sains Indonesia, 3(1): 1-17.

Modigliani, Franco, dan Merton H. Miller. 1963. Corporate income taxes and the cost of capital: A correction. American Economic Review, 53(3): 433-443.

Nurhayati, Mafizatun. 2013. Profitabilitas, likuiditas dan ukuran perusahaan pengaruhnya terhadap kebijakan dividen dan nilai perusahaan sektor non jasa. Jurnal Keuangan dan Bisnis, 5 (2): 144-153.

Parmar, Bidhan L., R. Edward Freeman, Jeffrey S. Harrison., Andrew C. Wicks, Lauren Purnell, dan Simone de Colle. 2010. Stakeholder theory: The state of the art. The Academy of Management Annals, 4(1): 403-445.

Penman, Stephen. 2013. Financial Statement Analysis and Security Valuation. 5th edition. McGraw-Hill, New York.

Plumlee, Marlene, Darrell Brown, Rachel M. Hayes dan R. Scott Marshall. 2015. Voluntary environmental disclosure quality and firm value: Further evidence. Journal of Accounting and Public Policy, 34(4): 336-361. 
Prasetyorini, Bhekti Fitri. 2013. Pengaruh ukuran perusahaan, leverage, price earning ratio dan profitabilitas terhadap nilai perusahaan. Jurnal Ilmu Manajemen, 1(1): 183-196.

Richardson, A. dan M. Welker. 2001. Social disclosure, financial disclosure and the cost of equity capital. Accounting, Organizations and Society, 26(7/8): 597-616.

Scott, William R. 2012. Financial accounting theory. 6th edition. Prentice Hall, New Jersey.

Schadewitz, Hannu, dan Mikael Niskala. 2010. Communication via responsibility reporting and its effect on firm value in Finland. Corporate Social Responsibility and Environmental Management, 17(2): 96-106.

Servaes, Henri, dan Ane Tamayo. 2013. The impact of corporate social responsibility on firm value: The role of customer awareness. Management

Setiadi, Iwan. 2016. Stakeholders, Pengungkapan Lingkungan dan Nilai Perusahaan. Disertasi Program Doktor Ilmu Ekonomi Universitas Sebelas Maret, Surakarta.

Suhardjanto, Djoko dan Shinta Nugraheni. 2012. Pengaruh corporate social responsibility (CSR) disclosure terhadap nilai perusahaan (Studi Empiris di Bursa Efek Indonesia). Jurnal Akuntansi, 16(02): 162-177.

Wahidahwati. 2002. Pengaruh kepemilikan manajerial dan kepemilikan institusional pada kebijakan utang perusahaan : Sebuah perspektif teori agensi. JRAI, 5(1): 1-16.

Wijaya, Bayu Irfandi dan I.B. Panji Sedana. 2015. Pengaruh profitabilitas terhadap nilai perusahaan (Kebijakan dividen dan kesempatan investasi sebagai variabel mediasi). E-Jurnal Manajemen Unud, 4(12): 4477-4500.

Wulandari, Dwi Retno. 2013. Pengaruh profitabilitas, operating leverage, likuiditas terhadap nilai perusahaan dengan struktur modal sebagai intervening. Accounting Analysis Journal, 2(4): 455-463. 